Article

\title{
Augmented Reality (AR)-Based Intervention to Enhance Awareness of Fine Dust in Sustainable Environments
}

\author{
Jung Rim Huh ${ }^{1}$, In-Jo Park ${ }^{2}$, Young Sunwoo ${ }^{3}$, Hyo Jeong Choi ${ }^{4}$ and Kon Joon Bhang ${ }^{5, *(0)}$ \\ 1 Social Eco Tech Institute, Konkuk University, Seoul 05029, Korea; jr529@naver.com \\ 2 Department of Psychology, Henan University, Kaifeng 475001, China; park@henu.edu.cn \\ 3 Department of Civil and Environmental Engineering, Konkuk University, Seoul 05029, Korea; \\ ysunwoo@konkuk.ac.kr \\ 4 Department of Environmental Engineering, Konkuk University, Seoul 05029, Korea; \\ chlgywjd2646@gmail.com \\ 5 Department of Civil Engineering, Kumoh National Institute of Technology, Gumi 39177, Korea \\ * Correspondence: bhang.1@kumoh.ac.kr
}

Received: 16 October 2020; Accepted: 18 November 2020; Published: 25 November 2020

\begin{abstract}
Education on fine dust is a challenging field, as it must explain abstract phenomena and accompany the demands for behavioral changes. This research studied whether the adoption of augmented reality (AR) technology can effect change in student perspectives with a view to improving the attitudes of passive students regarding fine dust-related matters. With regard to student awareness, $94.0 \%$ of students responded that the issue of fine dust in Korea is severe; the higher the degree of interest they had in fine dust, the more severe they perceived the issue to be. On the perceived severity of fine dust in schools, $47.8 \%$ viewed it as severe; again, the level differed by the degree of interest. Students $(80 \%)$ who received a traditional education on fine dust expressed dissatisfaction. The effect of using AR in experiential learning in fine dust environmental education has shown enhanced results compared to before receiving the education, notably in the group with a low degree of interest in fine dust and the group without prior experience in fine dust environmental education. Likewise, in the satisfaction rate for AR-based education on fine dust, $72.5 \%$ of participants responded that they had enjoyed the class, $75.9 \%$ showed active participation, and $80.0 \%$ felt that the content of the education was useful. Considering that the objective of fine dust environmental education is not based on understanding a theory but on maintaining individual health through practice in real life, the use of $\mathrm{AR}$ in fine dust environmental education as applied in this study may be interpreted as having a certain level of effect. Additionally, our results demonstrate that the use of AR in classes is effective in arousing students' interest and inducing participation for better engagement in learning activities, which is, consequently, effective in enhancing the understanding of learning materials by students.
\end{abstract}

Keywords: sustainable environment; fine dust; augmented reality; educational effect; perception; attitude

\section{Introduction}

The problem of air quality has resurfaced in Korea since the 1980s, and around 2010, as a new environmental problem. Due to the harmful effects of fine dust on the human body, the government has invested considerably in the development of new technologies and the disclosure of information to the public for the enhancement of air quality. However, air quality issues in Korea cannot be resolved easily in a short period of time, as this requires the joint efforts of neighboring countries. Due to the difficulty in installing air purification systems in large facilities, it is of dire importance to understand 
that the ultimate measure is to ensure that individuals have the will and attitude for self-protection from fine dust.

However, according to a survey in 2017 by the Green Consumer Network in Korea, 93.8\% of the population were aware of the harmful effects of fine dust, but only four out of 10 people wore masks due to the inconvenience of wearing them and doubts on the performance of their filters. Likewise, while $94.7 \%$ of the respondents recognized that the damage caused by the increase in fine dust concentrations is severe, raising awareness of the potential health risks seems necessary, as only $63.4 \%$ of respondents felt discomfort or experienced health issues caused by fine dust, whereas $71.9 \%$ felt discomfort from restrictions on outdoor activities, $70.5 \%$ experienced visual discomfort, and $67.6 \%$ experienced psychological discomfort. In other words, people do not commonly acknowledge the real danger of fine dust or feel the need to tackle the problem [1].

Therefore, the Ministry of Environment developed a simulator for fine dust education, (1) to engrave the harmfulness of fine dust in the minds of the public and students, and (2) to improve the attitude and raise awareness of the public to actively take action against fine dust at an individual level. They sought to find a new educational direction for the enhancement of public awareness and attitudes, for which they took into consideration augmented reality (AR) simulations as a new means of learning. Consequently, the Ministry developed an AR simulator environmental education program for fine dust experiential learning.

Augmented Reality (AR) is a computer graphics technology that composites virtual objects or information onto the real world to make them appear as objects that exist in reality. According to a study by [2], the educational value of AR has recently increased by a significant level, and AR will emerge as an important tool to enhance learning results. Users will be able to recognize real-life objects through the displayed images and acquire information that is conveyed through visualized virtual objects in an experiential method of learning. Such coexistence of virtual objects and the real environment can enable learners to specifically understand complex spatial relationships and abstract concepts [3,4]. It also delivers real-life experience and knowledge through a sense of engagement that no other technology can provide [5]. This fact is very important in terms of environmental sustainability because with AR-based intervention, our knowledge and experience can stimulate our motivation, significantly changing our attitudes toward environmental issues. In this respect, AR, as an educational tool, plays an essential role in maintaining and improving the environment by means of education on specific issues such as fine dust. In fact, AR technology has already been used to promote the development of higher levels of education in terms of economic, social, and environmental sustainability [6].

AR only requires small computers and cameras, such as tablets and mobile phones, that are used to build the environment, and utilizes software to visualize information. The camera displays an image of an area visible through the screen, while markers are used to composite a virtual object onto the corresponding area on the screen. Users move the markers to respond to the overlaid virtual objects [7]. Because virtual objects and information are displayed according to the user's responses, the user has to actively respond to the AR system and acknowledge the information for data exploration. With the development of computers and portable devices, such technology is able to provide high-level information and display various phenomena, with visual effects and hands-on experiences, that are otherwise impossible to portray. Hence, AR is widely used in the field of education. The areas in which AR is particularly effective and of high value are those where the subject is impossible to directly observe in the real world, those that explain complex phenomena, those for which experiments are impossible to execute, and those with high potential risk [8,9]. Additionally, AR responds to the user, enabling learners to manipulate the material from diverse perspectives [10].

It has been argued that AR has great potential for educational purposes, and has seven distinguishing characteristics: learning content in a three-dimensional perspective, ubiquitous traits, collaboration and location learning, learner presence, immediacy and engagement, visualization of the invisible, and connection between formal and informal learning [11],. Students' understanding 
can be enhanced through three-dimensional objects, which may be useful in teaching anatomy [12], astronomy [10], and geography [13]. These features of AR deliver a highly realistic learning experience by providing information combined with the real world through virtual cognitive information, such as sound, touch, and video [14].

The use of AR in education does not provide only merits [15]. The meta-analysis of [16] claims that three-dimensional visualization technology produces considerably improved results in the acquisition of spatial knowledge. However, the study did not always produce the same results, especially among students of anatomy, as the improvement was visible only for junior students. Other studies have shown that education with the use of technology is not always beneficial compared to traditional teaching methods [17-20].

However, judging from the fact that AR-based educational activities were shown in existing research to be helpful in learning, AR is expected to have an appropriate positive effect on education on fine dust. No research was found on the effect of AR-based education on fine dust, and the usefulness of development contents cannot be assessed without verification of the effect of fine dust education. Therefore, the effects of AR developed through this research have been confirmed to be valid on experiential education, such as for fine dust. In particular, it is impossible to provide education in the form of site visits and observation for environmental education on fine dust. Thus, it is expected that this research will provide information on how AR can be used as a learning tool for environmental education - and for fine dust education in particular — to bring about positive effects and provide insight into how the changes occur in students' awareness and attitudes toward this issue.

\section{Materials and Methods}

\subsection{Background}

According to a study by [21], field trips or tours were the most widely valued teaching method by teachers in environment-related classes. However, field trips or tours present challenges due to a lack of relevant programs, safety issues, unexpected weather changes, and a lack of locations to allow for on-site experiences.

Therefore, VR/AR technology has been used in various fields of education to attempt to create virtual field trips in classrooms and verify their effectiveness (Table 1). According to [22], VR/AR-based education effectively enhanced various learning capabilities, such as students' interest, self-directed learning skills, cooperation skills, and critical-thinking skills. One study on environmental education using immersive VR (IVR) which focused on the change of marine ecosystems due to the impact of climate change demonstrated that IVR-based experiential learning could help students to learn complex and abstract notions associated with ocean acidification, thus reinforcing eco-friendly attitudes and strengthening the effect of learning [23].

\subsection{Research Design}

This study provided fine dust environmental education to 182 first-year high school students in Seoul, as shown in Figure 1. Two hours of theoretical classes were conducted to provide knowledge and information on fine dust. A week later, another class was held for the same target students using fine dust educational contents with augmented reality (AR) technology. Surveys were conducted before and after the fine dust education to investigate changes in students' awareness and attitudes.

\subsection{Method of AR-Based Education}

The education on fine dust was conducted for one hour at a time for two classes (Table 2, Figure 2). Different educational subjects and teaching methods were adopted for each class. The first class comprised basic theories, such as the concept of fine dust, its sources, and risks to the human body. Lectures and discussions were utilized as methods of learning for the first class. More in-depth topics were covered in the second class, such as fine dust inflow routes, pollution levels, and behavioral tips, 
and a portable tablet-based AR system was adopted. As for the contents of the education, marker-based (Object/Image) technology was utilized.

Table 1. Research on VR/AR-based education in international journals.

\begin{tabular}{|c|c|c|}
\hline Title (Reference) & Abstract & Conclusions \\
\hline $\begin{array}{l}\text { EcoMOBILE: Integrating } \\
\text { augmented reality and } \\
\text { probeware with } \\
\text { environmental education } \\
\text { field trips [24] }\end{array}$ & $\begin{array}{l}\text { The EcoMOBILE project combined an } \\
\text { augmented reality (AR) experience with } \\
\text { the use of environmental probeware } \\
\text { during a field trip to a local } \\
\text { pond environment. }\end{array}$ & $\begin{array}{l}\text { - Improved student interaction with the } \\
\text { pond in a format that was } \\
\text { student-centered rather } \\
\text { than teacher-directed. } \\
\text { - } \quad \text { Deeper understanding. } \\
\text { - Expanded opportunities to engage in } \\
\text { activities that resemble } \\
\text { scientific practice. }\end{array}$ \\
\hline
\end{tabular}

Advantages and challenges associated with augmented reality for education: A systematic review of the literature [25]
This study presented a systematic review of the literature on AR used in educational settings considering factors such as publication year, learner type, technologies in AR, and the advantages and challenges of using AR in educational settings
Increase in the number of AR studies during the last four years

- The most widely reported advantage of $\mathrm{AR}$ is that it promotes enhanced learning.

- $\quad$ Some noted challenges imposed by AR were usability issues and frequent technical problems.
Mobile Augmented Reality:

The Potential for

Education [26]
This paper reviewed several studies on mobile augmented reality and exemplified the potential of the technology for education.
The effectiveness of AR can be further extended when it is combined with other types of technology such as mobile devices.

\begin{tabular}{|c|c|c|c|}
\hline 1) Pre-survey & 2) Theoretical Lecture & 3) AR Practical Training & 4) Post-survey \\
\hline $\begin{array}{l}\text { Textbook Development } \\
\text { - Recognition and } \\
\text { Attitudes } \\
\text { - Experience in Fine dust } \\
\text { education }\end{array}$ & $\left\{\begin{array}{l}\multicolumn{1}{c}{\text { Lesson } 1} \\
\text { - Definition and Features } \\
\text { - Human health risk } \\
\text { - Emergency response } \\
\text { instructions }\end{array}\right.$ & $\left\{\begin{array}{l}\multicolumn{1}{c}{\text { Lesson } 2} \\
\cdot \begin{array}{l}\text { Application operation } \\
\text { manual }\end{array} \\
\text { - Experience of pollution } \\
\text { and response instructions }\end{array}\right.$ & $\begin{array}{l}\text { Effectiveness Checks } \\
\text { - Change of perception } \\
\text { and attitude } \\
\text { - Participation and interest } \\
\text { - Educational satisfaction }\end{array}$ \\
\hline
\end{tabular}

Figure 1. Flow of AR-based education on fine dust.

Table 2. Overview of the instruction of AR-based education on fine dust.

\begin{tabular}{llll}
\hline & \multicolumn{1}{c}{ Lesson 1 } & \multicolumn{1}{c}{ Lesson $\mathbf{2}$} \\
\hline Title & $\begin{array}{l}\text { Fine dust concepts and basic } \\
\text { theory }\end{array}$ & Title & AR practical training \\
\hline $\begin{array}{l}\text { Teaching } \\
\text { Method }\end{array}$ & Lecture, discussion & $\begin{array}{l}\text { Teaching } \\
\text { Method }\end{array}$ & Lectures, practice, discussions, quiz \\
\hline & $\begin{array}{l}\text { Concepts of Fine dust } \\
\text { Measurement method } \\
\text { The relationship between Fine } \\
\text { dust and weather }\end{array}$ & Contents & $\begin{array}{l}\text { [Step 1] } \\
\text { AR Application operation } \\
\text { AR Application practice } \\
\text { [Step 2] } \\
\text { Experience educational contents of } \\
\text { fine dust using AR }\end{array}$ \\
\hline
\end{tabular}




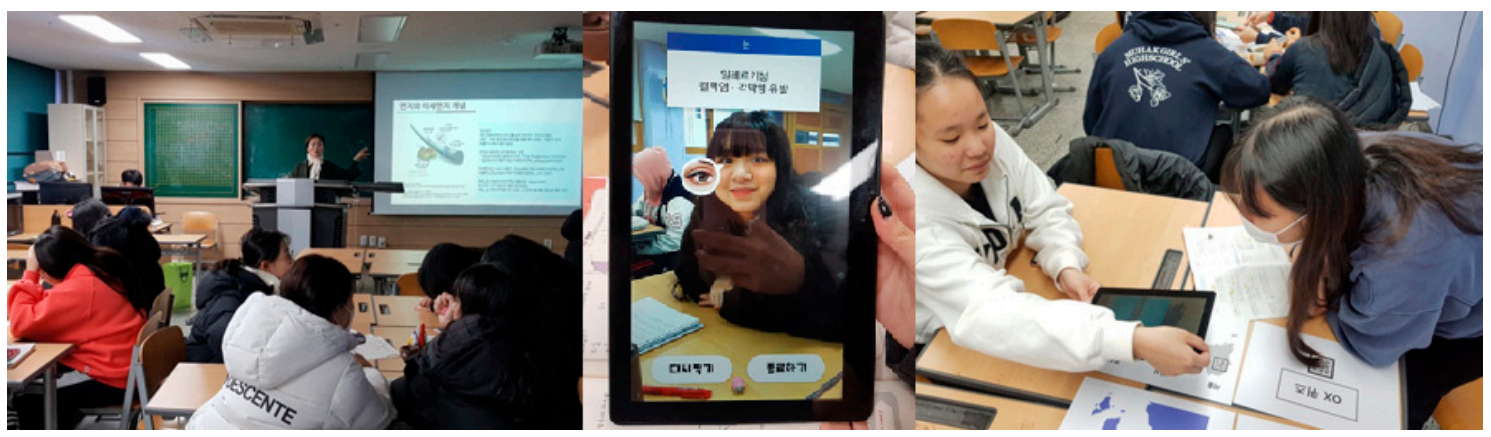

Figure 2. Students receiving AR-based education.

The specific method of performing fine dust education using AR consisted of two stages: In the first phase, students were trained on the basic operation of the application before the official lesson to better understand AR technology. As an example of AR technology implementation, a magical newspaper with moving images in the widely known movie "Harry Potter" was presented to draw the students' interest. Afterward, students practiced the method of direct manipulation. They registered pictures or letters that they created as markers and used the camera to recognize the markers in the application, which were displayed as animated characters singing in three dimensions. The subtopics covered in the second phase were the inflow of fine dust into the human body, the route and risk to each body organ, the duration from inflow to discharge, and the principle of removing fine dust using artificial rainfall technology. Each topic was developed with a short educational video of 1 to 5 min, and each video's thumbnail (representative image of the video) was preregistered as a marker. When the camera recognized the marker, the video was overlaid onto the image through the display screen. Additionally, flexible and self-directed learning was encouraged in consideration of each student's progress rate and interest by providing learning tools and materials that could be used autonomously. Figure 3 shows the learning materials used in the class.
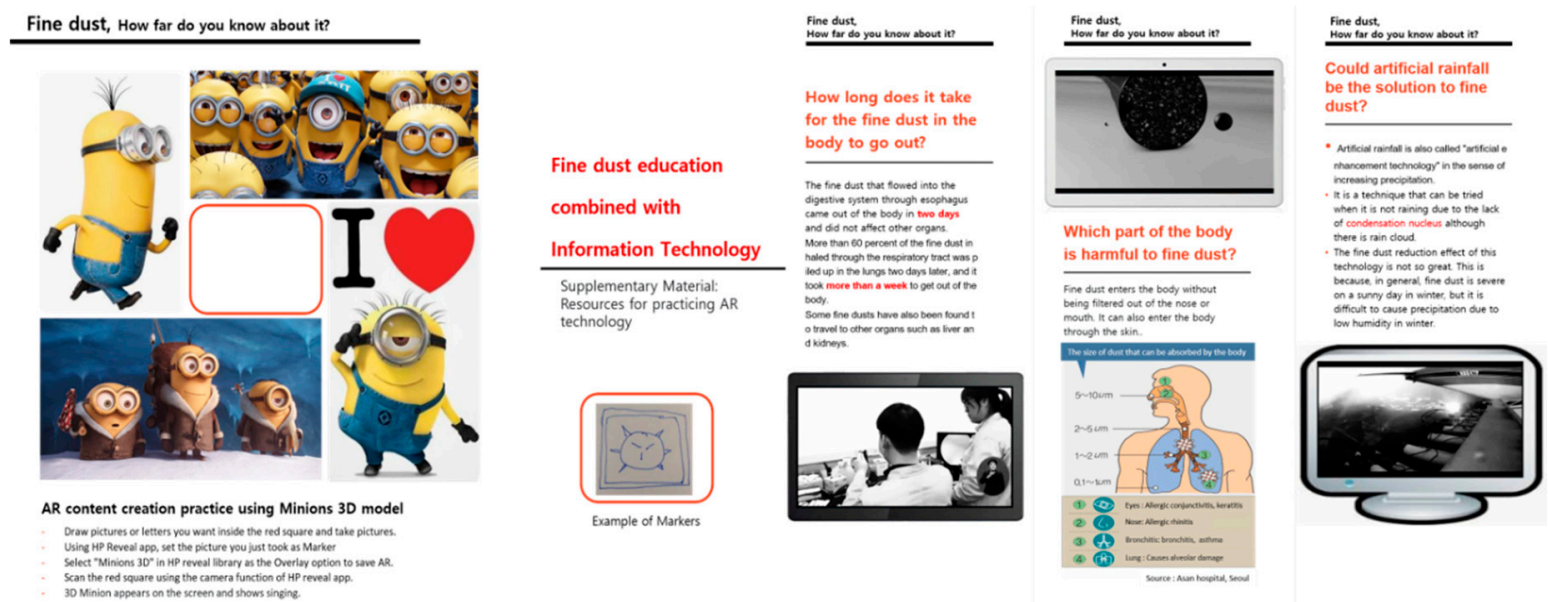

Figure 3. Extracts from the booklet for AR Markers applied to fine dust education.

\subsection{Survey}

The survey targeted a total of 182 female, first-year high school students. Common questions were asked in the pre- and post-test surveys, with questions on awareness of and attitudes to fine dust. The post-test survey had an additional section inquiring about the level of satisfaction with the AR-based fine dust education. The method of the survey used was interviews with the participants. Each question in the survey used a Likert scale from one to five, with one representing strongly negative or strongly disagree and five representing strongly positive or strongly agree. 


\subsection{Method of Analysis}

The section on measuring student's attitudes toward fine dust was composed of 12 questions (Table 3). All items were found to have a certain correlation, and Cronbach's $\alpha$ was calculated as 0.815 . The 12 items for measuring students' attitudes could thus be deemed reliable.

Table 3. Questions for Measuring Attitude.

\begin{tabular}{l} 
Questions \\
\hline (Q1) Check weather conditions through broadcasting, the Internet, etc. \\
(Q2) I adjust my commuting time to and from school and check whether the school is closed. \\
(Q3) I prepare personal hygiene products such as yellow dust masks, handkerchiefs, and tissues. \\
(Q4) If yellow dust or fine dust is severe, make sure to wear a mask when going to and from school. \\
(Q5) On days with high concentrations of fine dust, I close the windows and avoid outdoor activities. \\
(Q6) I perform personal hygiene activities thoroughly, such as washing hands and brushing teeth. \\
(Q7) Thorough recycling and cleaning. \\
(Q8) Not running or playing too much in the classroom. \\
(Q9) I try to reduce the amount of fine dust when I change into or out of my gym clothes or during physical \\
education classes. \\
(Q10) Ventilate indoor air after yellow dust and fine dust warnings. \\
(Q11) I use an air purifier, humidifier, etc. to maintain clean air indoors. \\
(Q12) Periodically ventilate indoor air on days when yellow dust and fine dust are not severe.
\end{tabular}

This study adopted a quantitative method for data analysis to observe changes in the Likert scale. Descriptive statistics were calculated with the overall mean, each individual mean, standard deviation, and maximum and minimum figures.

\section{Results}

\subsection{Awareness of Fine Dust}

As shown in Table 4, regarding students' interest in fine dust, $86.1 \%$ of the total (182) showed a higher than moderate degree of interest, whereas $13.1 \%$ showed no interest. Furthermore, $55.6 \%$ of students with experience in fine dust-related environmental education in elementary, middle, and high schools had a higher than moderate degree of interest. In comparison, $45.8 \%$ had no experience of receiving such education.

Table 4. Statistics on students' interest in fine dust.

\begin{tabular}{ccccccccc}
\hline \multirow{2}{*}{ Type } & \multirow{2}{*}{ Sample } & \multicolumn{7}{c}{ Likert Scale } \\
\cline { 3 - 7 } & & & $\mathbf{1}$ & $\mathbf{2}$ & $\mathbf{3}$ & $\mathbf{4}$ & $\mathbf{5}$ & \multirow{2}{*}{ Mean (Std.) } \\
\hline Total & & 182 & 1.6 & 11.5 & 35.7 & 42.9 & 8.2 & $3.45(0.86)$ \\
\hline \multirow{2}{*}{ Education Experience } & Yes & 99 & 1.0 & 9.1 & 34.3 & 45.5 & 10.1 & $3.55(0.84)$ \\
& No & 83 & 2.4 & 14.5 & 37.3 & 39.8 & 6.0 & $3.33(0.88)$ \\
\hline
\end{tabular}

As shown in Table 5, 94.0\% of the students responded that Korea's fine dust problem was severe. As for the differences in the level of perceived severity based on the degree of interest in fine dust, $100 \%$ of students with a high degree of interest perceived the issue as being severe; $93.9 \%$ of students with a moderate degree of interest perceived it as being severe, and $70.8 \%$ of students not interested in the issue perceived it as being severe. Such results were statistically significant $(F=22.196, p<0.001)$. 
Table 5. Awareness of the severity of fine dust problems in Korea based on the degree of interest in fine dust and educational experience.

\begin{tabular}{|c|c|c|c|c|c|c|c|}
\hline \multirow{2}{*}{\multicolumn{2}{|c|}{ Type }} & \multirow{2}{*}{ Sample } & \multicolumn{3}{|c|}{ Likert Scale } & \multirow{2}{*}{ Ave. (Std.) } & \multirow{2}{*}{$t / F$} \\
\hline & & & 1 & 2 & 3 & & \\
\hline \multicolumn{2}{|c|}{ Total } & 182 & 48.9 & 45.1 & 6.0 & $4.43(0.61)$ & \\
\hline \multirow{3}{*}{$\begin{array}{c}\text { Interest on } \\
\text { Fine Dust }\end{array}$} & (A) High & 93 & 67.7 & 32.3 & 0 & $4.68(0.47)$ & $F=22.196$ \\
\hline & (B) Moderate & 65 & 30.8 & 63.1 & 6.2 & $4.25(0.56)$ & $p=0.000$ \\
\hline & (C) Low & 24 & 25.0 & 45.8 & 29.2 & $3.96(0.75)$ & $(\mathrm{A}>\mathrm{B}, \mathrm{C})$ \\
\hline Education & Yes & 99 & 51.5 & 46.5 & 2.0 & $4.49(0.54)$ & $t=1.590$ \\
\hline Experience & No & 83 & 45.8 & 43.4 & 10.8 & $4.35(0.67)$ & $p=0.114$ \\
\hline
\end{tabular}

This finding indicates that the greater the degree of interest students had in fine dust, the more aware they were of its severity. As for the differences in the level of perceived severity based on the educational experience on fine dust received in elementary, middle, and high schools, $98.0 \%$ of students with such experience perceived the issue as being severe, whereas $89.2 \%$ of students without prior educational experience perceived it as being severe. However, there was no significant difference between the groups with or without educational experience.

Regarding the severity of fine dust problem in schools (Table 6), $44.0 \%$ of students were aware of its severity, with responses divided into serious $(33.0 \%)$ and very serious $(11.0 \%)$. Depending on the degree of interest in fine dust, $57.0 \%$ of students with a high degree of interest (A) perceived the fine dust in schools as being severe, and $25 \%$ of students with a low degree of interest (C) perceived the issue as being severe. Such results were statistically significant $(F=7.574, p<0.01)$.

Table 6. Awareness of fine dust problems in Korea based on the degree of interest in fine dust and educational experience.

\begin{tabular}{|c|c|c|c|c|c|c|c|c|c|}
\hline \multirow{2}{*}{\multicolumn{2}{|c|}{ Type }} & \multirow{2}{*}{ Sample } & \multicolumn{5}{|c|}{ Likert Scale } & \multirow{2}{*}{ Ave. (Std.) } & \multirow{2}{*}{$t / F$} \\
\hline & & & 1 & 2 & 3 & 4 & N/A & & \\
\hline \multicolumn{2}{|c|}{ Total } & 182 & 11.0 & 33.0 & 47.8 & 7.7 & 0.5 & $3.48(0.79)$ & \\
\hline \multirow{3}{*}{$\begin{array}{l}\text { Interest on } \\
\text { Fine Dust }\end{array}$} & (A) High & 93 & 16.1 & 40.9 & 37.6 & 5.4 & 0 & $3.68(0.81)$ & $F=7.574$ \\
\hline & (B) Moderate & 65 & 6.2 & 26.2 & 60.0 & 6.2 & 1.5 & $3.33(0.69)$ & $p=0.001$ \\
\hline & (C) Low & 24 & 4.2 & 20.8 & 54.2 & 20.8 & 0 & $3.08(0.78)$ & $(\mathrm{A}>\mathrm{B}, \mathrm{C})$ \\
\hline Education & Yes & 99 & 10.1 & 34.3 & 53.5 & 2.0 & 0 & $3.53(0.7)$ & $t=0.914$ \\
\hline Experience & No & 83 & 12.0 & 31.3 & 41.0 & 14.5 & 1.2 & $3.41(0.89)$ & $p=0.362$ \\
\hline
\end{tabular}

As for the educational experience, $44.4 \%$ of students with experience and $43.3 \%$ of students without experience acknowledged the severity of the issue, which had no statistical significance. The level of perceived severity of fine dust problems in schools varied depending on the degree of interest students had in the fine dust problem and did not correlate with previous experience in receiving fine dust-related education.

\subsection{Attitude toward Fine Dust (Pretest Survey)}

Students' attitudes toward fine dust were at a moderate level, i.e., 3.35 (Figure 4). As for the attitude toward fine dust by survey item, the survey items with a higher than moderate degree of implementation of activities related to fine dust were $\mathrm{Q} 6=3.80, \mathrm{Q} 11=3.77$, and $\mathrm{Q} 5=3.63$, in descending order. The degree of implementation was relatively low for items Q9 $=2.70, \mathrm{Q} 2=2.93$, and Q3 $=2.94$. 


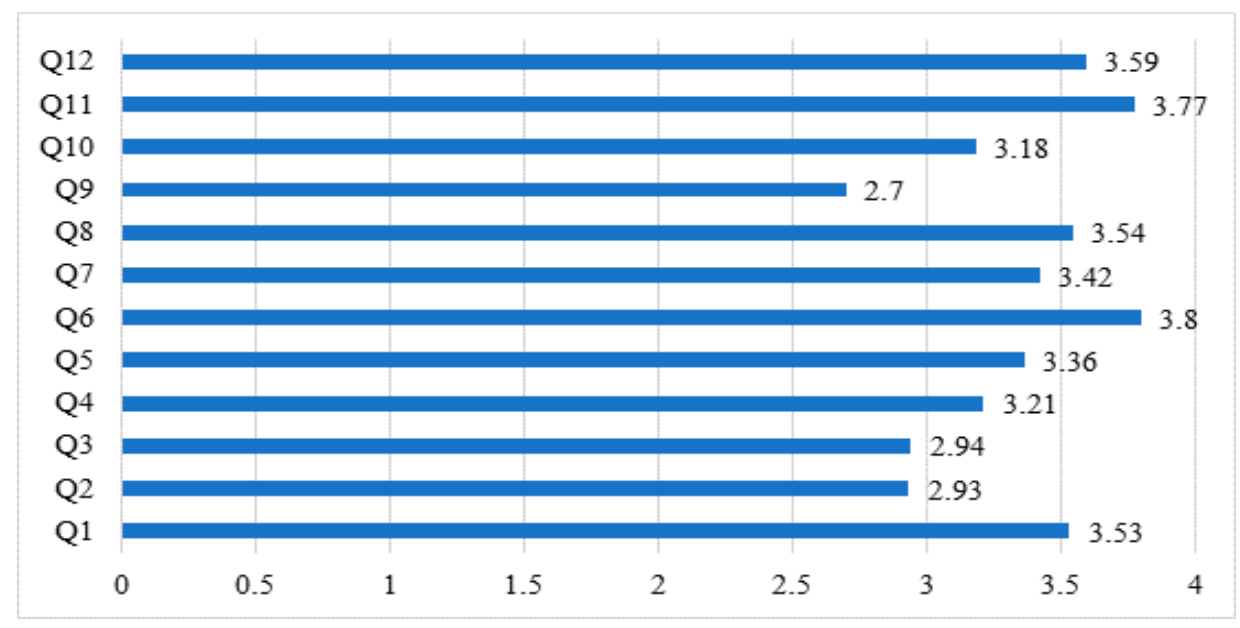

Figure 4. Attitude toward fine dust by survey item.

Attitudes based on the degree of interest in fine dust averaged 3.63 for the "High (A)" group, 3.14 for the "Moderate (B)" group, and 2.83 for the "Low" group. Such results were statistically significant $(F=27.204, p<0.001)$ (Table 7). This finding can be understood as demonstrating that the higher the degree of interest students show in fine dust, the higher their level of attitude was in responding to the issue.

Table 7. The degree of implementation of fine dust-related activities according to the degree of interest and educational experience.

\begin{tabular}{|c|c|c|c|c|}
\hline \multicolumn{2}{|c|}{ Type } & Sample & Mean (Std.) & $F / t$ \\
\hline \multicolumn{2}{|c|}{ Total } & 182 & $3.35(0.63)$ & \\
\hline \multirow{3}{*}{$\begin{array}{l}\text { Interst on } \\
\text { Fine Dust }\end{array}$} & (A) High & 93 & $3.63(0.56)$ & \multirow{3}{*}{$\begin{array}{c}F=27.204 \\
p=0.000 \\
(\mathrm{~A}>\mathrm{B}, \mathrm{C})\end{array}$} \\
\hline & (B) Moderate & 65 & $3.14(3.14)$ & \\
\hline & (C) Low & 24 & $2.83(0.63)$ & \\
\hline \multirow{2}{*}{$\begin{array}{l}\text { Education } \\
\text { Experience }\end{array}$} & Yes & 99 & $3.46(0.63)$ & \multirow{2}{*}{$\begin{array}{l}t=2.583 \\
p=0.011\end{array}$} \\
\hline & No & 83 & $3.22(0.62)$ & \\
\hline
\end{tabular}

Concerning differences in the level of attitude based on educational experience, students with such educational experience had a slightly higher degree of implementation of fine dust-related activities (average: 3.46 ) than those with no prior relevant education (average: 3.22 ). These results show significant differences between educational experience and attitude $(t=2.583, p<0.05)$, which may be understood as demonstrating that the level of attitude increases with educational experience (Table 7).

\subsection{Level of Satisfaction with the Most Recent Education Received on Fine Dust (Pretest Survey)}

The majority of the most recent environmental education on fine dust received by the students was in the form of "lecture and video"; only $8.9 \%$ was conducted in the form of experiential learning (group activities, etc.) (Table 8).

Concerning the education methods, many lessons were taught with "lecture and video" both within and outside schools. However, the classes taught in schools used this approach more frequently ( $83.1 \%$ of the time) than those taught elsewhere $(77.8 \%)$. This indicates differences in education methods depending on the location of education with statistical significance $\left(\chi^{2}=27.823, p<0.001\right)$. 
Table 8. Method of education in the most recent environmental education received on fine dust.

\begin{tabular}{|c|c|c|c|c|c|c|}
\hline \multicolumn{2}{|c|}{ Type } & Sample & Lecture-Video & $\begin{array}{l}\text { Experience } \\
\text { (Group) } \\
\text { Activities }\end{array}$ & N/A & $x^{2}$ \\
\hline \multicolumn{2}{|c|}{ Total } & 101 & 80.2 & 8.9 & 10.9 & \\
\hline \multirow{3}{*}{ Education Place } & In school & 89 & 83.1 & 7.9 & 9.0 & \multirow{3}{*}{$\begin{aligned} \chi^{2} & =27.823 \\
p & =0.000\end{aligned}$} \\
\hline & Outside school & 9 & 77.8 & 22.2 & 0.0 & \\
\hline & N/A & 3 & 0.0 & 0.0 & 100.0 & \\
\hline \multirow{3}{*}{$\begin{array}{l}\text { Education } \\
\text { Teacher }\end{array}$} & School teacher & 13 & 100.0 & 0.0 & 0.0 & \multirow{3}{*}{$\begin{aligned} \chi^{2} & =63.700 \\
p & =0.000\end{aligned}$} \\
\hline & External Instructor & 81 & 84.0 & 11.1 & 4.9 & \\
\hline & N/A & 7 & 0.0 & 0.0 & 100.0 & \\
\hline
\end{tabular}

Unit: Number of people, \%. Difference verification excludes no-response (N/A).

The differences based on instructors were as follows: education provided by school affiliated teachers was entirely in the form of lectures and videos, whereas in the case of guest instructors, most classes were taught with "lecture and video" (84.0\%), while some were in the form of "experiential learning (group activities, etc.)" (11.1\%), which indicates that guest instructors utilized relatively more diverse educational methods. The teaching methods in fine dust environmental education were found to have differences depending on the instructor with statistical significance $\left(\chi^{2}=63.700, p<0.001\right)$

To the question about the level of satisfaction with the most recent environmental education on fine dust, the majority of students responded "Moderate" (52.5\%), followed by "Satisfied" (30.7\%); only $9.9 \%$ indicated that they were "Dissatisfied"(Table 9$)$.

Table 9. Level of satisfaction with the most recent environmental education received on fine dust.

\begin{tabular}{|c|c|c|c|c|c|c|c|c|c|c|}
\hline \multirow{2}{*}{\multicolumn{2}{|c|}{ Type }} & \multirow[b]{2}{*}{ Sample } & \multicolumn{7}{|c|}{ Likert Scale } & \multirow[b]{2}{*}{$t$} \\
\hline & & & 1 & 2 & 3 & 4 & 5 & N/A & $\begin{array}{l}\text { Mean } \\
\text { (Std.) }\end{array}$ & \\
\hline \multicolumn{2}{|c|}{ Total } & 101 & 3.0 & 6.9 & 52.5 & 26.7 & 4.0 & 6.9 & $3.23(0.78)$ & \\
\hline \multirow{3}{*}{$\begin{array}{l}\text { Education } \\
\text { Place }\end{array}$} & In school & 89 & 3.4 & 6.7 & 55.1 & 25.8 & 4.5 & 4.5 & $3.22(0.79)$ & \multirow{3}{*}{$\begin{array}{c}t=-0.399 \\
p=0.691\end{array}$} \\
\hline & $\begin{array}{l}\text { Outside } \\
\text { school }\end{array}$ & 9 & 0.0 & 11.1 & 44.4 & 44.4 & 0.0 & 0.0 & $3.33(0.71)$ & \\
\hline & N/A & 3 & 0.0 & 0.0 & 0.0 & 0.0 & 0.0 & 100.0 & - & \\
\hline \multirow{3}{*}{$\begin{array}{c}\text { Education } \\
\text { Teacher }\end{array}$} & School & 13 & 0.0 & 7.7 & 76.9 & 15.4 & 0.0 & 0.0 & $3.08(0.49)$ & \multirow{3}{*}{$\begin{array}{c}t=-1.238 \\
p=0.228\end{array}$} \\
\hline & External & 81 & 2.5 & 7.4 & 53.1 & 29.6 & 4.9 & 2.5 & $3.28(0.78)$ & \\
\hline & N/A & 7 & 14.3 & 0.0 & 0.0 & 14.3 & 0.0 & 71.4 & $2.50(2.12)$ & \\
\hline \multirow{3}{*}{$\begin{array}{l}\text { Teaching } \\
\text { Method }\end{array}$} & $\begin{array}{l}\text { Lecture- } \\
\text { Video }\end{array}$ & 81 & 2.5 & 8.6 & 55.6 & 25.9 & 4.9 & 2.5 & $3.23(0.78)$ & \multirow{3}{*}{$\begin{array}{c}t=-0.394 \\
p=0.695\end{array}$} \\
\hline & Activities & 9 & 0.0 & 0.0 & 66.7 & 33.3 & 0.0 & 0.0 & $3.33(0.50)$ & \\
\hline & $\mathrm{N} / \mathrm{A}$ & 11 & 9.1 & 0.0 & 18.2 & 27.3 & 0.0 & 45.5 & 3.17 (1.17) & \\
\hline
\end{tabular}

Unit: Number of people, \%, Point. Mean (Std) and difference verification excludes no-response (N/A)

As for the level of satisfaction with the fine dust environmental education based on the location at which the students received it, "Moderate" (55.1\%) had the highest percentage for within schools, and "Moderate" (44.4\%) and "Satisfied" (44.4\%) were equal first for outside schools. The satisfaction level was higher for outside schools (average: 3.33) than for within (average: 3.22).

Regarding the level of satisfaction with the instructor, "Moderate" had the highest percentage for both affiliated teachers and guest instructors (affiliated teacher 76.9\%, guest instructor 53.1\%). The level of satisfaction, in descending order, was, on average, 3.28 for guest instructors and 3.08 for affiliated teachers. 
For the method of education, "Moderate" had the highest number of responses for both "lecture and video" and "experiential learning (group activities, etc.)" (lecture and video 55.6\%, experiential learning (group activities, etc.) 66.7\%). The level of satisfaction was higher for experiential learning (group activities, etc.) (average: 3.33) than for lecture and video (average: 3.23).

For responses of dissatisfaction $(n=10), 80.0 \%$ of students indicated that the lessons were "focused on theoretical background and thus uninteresting", which demonstrates the need for greater variety in the form of classes that can arouse the interest of students (Table 10).

Table 10. Reasons for dissatisfaction with the most recent environmental education received by students on fine dust.

\begin{tabular}{cccccc}
\hline Type & Sample & $\begin{array}{c}\text { Lack of } \\
\text { Information } \\
\text { Wanted to Know }\end{array}$ & $\begin{array}{c}\text { Difficult to } \\
\text { Understand }\end{array}$ & $\begin{array}{c}\text { Boring Because It Was } \\
\text { a Theory-Based Class }\end{array}$ \\
\hline \multirow{2}{*}{ Total } & & 10 & 30 & 10 & 80 \\
\hline \multirow{2}{*}{ Education Place } & In school & 9 & 33.3 & 11.1 & 77.8 \\
& Outside school & 1 & 0 & 0 & 100 \\
\hline \multirow{2}{*}{ Education Teacher } & School teacher & 1 & 0 & 0 & 100 \\
& External Instructor & 8 & 25 & 12.5 & 87.5 \\
& N/A & 1 & 100 & 0 & 0 \\
\hline \multirow{2}{*}{ Teaching Method } & Lecture-Video & 9 & 22.2 & 11.1 & 0 \\
& N/A & 1 & 100 & 0 & 0 \\
\hline
\end{tabular}

Regarding the reasons for dissatisfaction based on the location, the most common response was that the lessons were "focused on theoretical background and thus uninteresting" for both within and outside schools $(77.8 \%$ and $100.0 \%$ respectively). For in-school education, the response "lack contents that I wish to know" came in second, with 33.3\%.

With regard to the reasons for dissatisfaction with the instructor, the response that the lessons were "focused on theoretical background and thus uninteresting" was ranked first for classes taught by either affiliated teachers or guest instructors (affiliated teachers: $100.0 \%$, guest instructor: $87.5 \%$ ). Second in rank for reasons of dissatisfaction with guest instructors was "lack contents that I wish to know (25.0\%)."

As for the method of education, reasons for dissatisfaction with education in the form of lectures and videos were, in descending order, "focused on theoretical background and thus uninteresting $(88.9 \%)$ ", "lack contents that I wish to know (22.2\%)", and "difficult to understand (11.1\%)."

\subsection{Effect of AR-Based Fine Dust Education (Posttest Survey)}

Student's overall attitudes toward fine dust improved after the AR-based lessons (Table 11). The overall mean calculated before AR-based education was 3.35, which was a moderate level. By survey item, the items with a high degree of implementation were, in descending order, "I thoroughly perform personal hygienic activities, such as washing hands and brushing teeth" (average: 3.80), "I use an air purifier, humidifier, etc. to maintain clean air quality indoors" (average: 3.77), and "On days with high concentration of fine dust, I close the window and refrain from outdoor activities" (average: 3.63). On the other hand, items such as "I try to reduce the amount of fine dust when I change into or out of my gym clothes or during physical education classes" (average: 2.70), "I adjust the commuting time to and from school and check whether the school is closed" (average: 2.93), and "I prepare personal hygiene products such as yellow dust masks, handkerchiefs, and tissues" (average: 2.94) had a relatively low degree of implementation. The overall mean after the AR-based lessons was 4.23, an improvement of 0.88 . 
Table 11. Changes in the Attitude toward Fine Dust after Experiential Education.

\begin{tabular}{|c|c|c|c|c|c|c|c|c|}
\hline \multirow{2}{*}{\multicolumn{2}{|c|}{$\begin{array}{l}\text { Type } \\
\text { Total }\end{array}$}} & \multirow{2}{*}{$\begin{array}{c}\text { Sample } \\
182\end{array}$} & \multicolumn{2}{|c|}{$\begin{array}{c}\text { Before } \\
\text { Mean (Std.) }\end{array}$} & \multicolumn{2}{|c|}{$\begin{array}{c}\text { After } \\
\text { Mean (Std.) }\end{array}$} & \multirow{2}{*}{$\begin{array}{c}\begin{array}{r}\text { Diff. } \\
\text { (A-B) }\end{array} \\
0.88\end{array}$} & \multirow{2}{*}{$\begin{array}{c}t / Z \\
t=-12.299 \\
p=0.000\end{array}$} \\
\hline & & & 3.35 & $(0.63)$ & 4.23 & $(0.65)$ & & \\
\hline \multirow{3}{*}{$\begin{array}{l}\text { Degree of } \\
\text { Interest in } \\
\text { Fine Dust }\end{array}$} & High & 93 & 3.63 & $(0.56)$ & 4.22 & $(0.66)$ & 0.59 & $\begin{array}{c}t=-6.195 \\
p=0.000\end{array}$ \\
\hline & Moderate & 65 & 3.14 & (0.53) & 4.25 & $(0.61)$ & 1.11 & $\begin{array}{c}t=-10.724 \\
p=0.000\end{array}$ \\
\hline & Low & 24 & 2.83 & $(0.63)$ & 4.22 & $(0.75)$ & 1.39 & $\begin{array}{c}t=-6.017 \\
p=0.000\end{array}$ \\
\hline \multirow{2}{*}{$\begin{array}{l}\text { Learning } \\
\text { Experience }\end{array}$} & Yes & 99 & 3.46 & $(0.63)$ & 4.25 & $(0.69)$ & 0.79 & $\begin{array}{c}t=-7.692 \\
p=0.000\end{array}$ \\
\hline & No & 83 & 3.22 & $(0.62)$ & 4.21 & $(0.61)$ & 0.99 & $\begin{array}{c}t=-10.143 \\
p=0.000\end{array}$ \\
\hline \multirow{2}{*}{$\begin{array}{c}\text { AR } \\
\text { Utilization } \\
\text { Experience }\end{array}$} & Yes & 50 & 3.44 & $(0.74)$ & 4.32 & $(0.56)$ & 0.88 & $\begin{array}{c}t=-5.993 \\
p=0.000\end{array}$ \\
\hline & No & 132 & 3.32 & $(0.59)$ & 4.20 & $(0.68)$ & 0.88 & $\begin{array}{c}t=-10.750 \\
p=0.000\end{array}$ \\
\hline
\end{tabular}

The degree of interest in fine dust was shown to enhance the degree of implementation of fine dust-related activities, regardless of variations in the degree of interest. The degrees of interest were: $t=-6.195, p<0.001$ for "High", $t=10.724, p<0.001$ for "Moderate", and $t=-6.017, p<0.001$ for "Low", all of which were statistically significant. A particularly notable tendency was that the lower the initial degree of interest for the students, the greater the increase in the degree of implementation of fine dust-related activities after receiving AR-based education (High $=\Delta 0.59$, Moderate $=\Delta 1.11$, Low $=\Delta 1.39$ ).

Regarding the educational experience, the degree of implementation of fine dust-related activities was enhanced, regardless of prior experience with relevant education; this was statistically significant ("With" $t=-7.692, p<0.001$, "Without" $t=-10.143, p<0.001$ ). Students without experience in fine dust environmental education were inclined to show a more significant increase in the degree of implementation after the AR-based education ("With" $=\Delta 0.79$, "Without" $=\Delta 0.99$ ).

As for the experience with $\mathrm{AR}$, the degree of implementation of fine dust-related activities was enhanced, regardless of prior experience with AR in education; this was statistically significant ("With" $t=-5.993, p<0.001$, "Without" $t=-10.750, p<0.001$ ). No correlation was visible between experience with AR and the degree of implementation of fine dust-related activities, as the degree of implementation for students without experience was enhanced at the same level as for those with experience ("With" $=\Delta 0.88$, "Without" $=\Delta 0.88$ )

With regard to changes in the degree of implementation of fine dust-related activities after the AR-based experiential education, there was an increase in the degree of all 12 of the survey items (see Table 12), especially for the following items in descending order: "I try to reduce the amount of fine dust when I change into or out of my gym clothes or during physical education classes ( $\Delta 1.42)$ ", "I adjust the commuting time to and from school and check whether the school is closed $(\Delta 1.33)$ ", and "I prepare personal hygiene products such as yellow dust masks, handkerchiefs, and tissues $(\Delta 1.20) . "$ 
Table 12. Changes in each survey item regarding the degree of implementation of fine dust-related activities.

\begin{tabular}{ccccccc}
\hline Question & \multicolumn{2}{c}{ Before Mean (Std.) } & \multicolumn{2}{c}{ After Mean (Std.) } & Diff.(A-B) & $t$ \\
\hline Q1 & 3.53 & $(1.11)$ & 4.23 & $(0.81)$ & 0.70 & $t=-6.671, p=0.000$ \\
Q2 & 2.93 & $(1.20)$ & 4.26 & $(0.84)$ & 1.33 & $t=-12.015, p=0.000$ \\
Q3 & 2.94 & $(1.16)$ & 4.14 & $(0.89)$ & 1.20 & $t=-11.301, p=0.000$ \\
Q4 & 3.21 & $(1.22)$ & 4.25 & $(0.83)$ & 1.04 & $t=-9.526, p=0.000$ \\
Q5 & 3.63 & $(1.09)$ & 4.20 & $(0.91)$ & 0.57 & $t=-5.277, p=0.000$ \\
Q6 & 3.80 & $(0.90)$ & 4.33 & $(0.77)$ & 0.53 & $t=-5.668, p=0.000$ \\
Q7 & 3.42 & $(0.96)$ & 4.10 & $(0.98)$ & 0.68 & $t=-6.364, p=0.000$ \\
Q8 & 3.54 & $(1.15)$ & 4.20 & $(0.91)$ & 0.66 & $t=-5.889, p=0.000$ \\
Q9 & 2.70 & $(1.09)$ & 4.13 & $(0.90)$ & 1.42 & $t=-12.940, p=0.000$ \\
Q10 & 3.18 & $(1.08)$ & 4.21 & $(0.85)$ & 1.03 & $t=-9.884, p=0.000$ \\
Q11 & 3.77 & $(1.07)$ & 4.40 & $(0.75)$ & 0.63 & $t=-6.430, p=0.000$ \\
Q12 & 3.59 & $(1.08)$ & 4.35 & $(0.75)$ & 0.76 & $t=-7.384, p=0.000$ \\
\hline
\end{tabular}

Unit: Point.

\subsection{Level of Satisfaction with AR-Based Education}

Only $27.5 \%$ of students had used AR for educational purposes prior to the AR-based environmental education on fine dust. Therefore, it was the first time using educational AR technology for most of the students (Table 13).

Table 13. Degree of interest in environmental education using AR.

\begin{tabular}{cccccccccc}
\hline Type & & Sample & $\mathbf{1}$ & $\mathbf{2}$ & $\mathbf{3}$ & $\mathbf{4}$ & \multicolumn{2}{c}{$\begin{array}{c}\text { Mean (Std.) } \\
\text { (Point) }\end{array}$} & $\boldsymbol{F} / \boldsymbol{t}$ \\
\hline Total & & 182 & 1.1 & 19.8 & 39.6 & 39.6 & 4.18 & $(0.78)$ & \\
\hline \multirow{2}{*}{$\begin{array}{c}\text { Degree of Interest } \\
\text { in Fine Dust }\end{array}$} & High & 93 & 1.1 & 17.2 & 40.9 & 40.9 & 4.22 & $(0.76)$ & \\
\cline { 2 - 8 } & Moderate & 65 & 1.5 & 18.5 & 40.0 & 40.0 & 4.18 & $(0.79)$ & $F=0.728$ \\
\cline { 2 - 8 } & Low & 24 & 0.0 & 33.3 & 33.3 & 33.3 & 4.00 & $(0.83)$ & \\
\hline $\begin{array}{c}\text { Learning } \\
\text { Experience }\end{array}$ & Yes & 99 & 1.0 & 16.2 & 36.4 & 46.5 & 4.28 & $(0.77)$ & $t=2.036$ \\
\cline { 2 - 8 } $\begin{array}{c}\text { AR Utilization } \\
\text { Experience }\end{array}$ & Yes & 53 & 1.2 & 24.1 & 43.4 & 31.3 & 4.05 & $(0.78)$ & $p=0.043$ \\
\cline { 2 - 8 } & No & 132 & 1.5 & 21.2 & 38.6 & 38.6 & 4.14 & $(0.80)$ & $p=0.372$ \\
\hline
\end{tabular}

Unit: Number of persons, \%, Point. (1) Education experience was based on the entire experience of fine dust environment education in elementary, middle, and high schools. (2) AR utilization experience means experience using AR for educational purposes prior to practical fine dust environment classes.

On whether or not the students enjoyed the AR-based environmental education on fine dust (Table 13), "Relatively enjoyable (39.6\%)" and "Very enjoyable (39.6\%)" were two responses with the same highest percentage. Such a result indicates that AR-based education is effective at arousing interest in young people.

Concerning the degree of enjoyment based on the degree of interest in fine dust, "Enjoyable" ("High" 81.8\%, "Moderate" 80.0\%, "Low" 66.6\%) had the highest number of responses, regardless of the degree of interest. The degree of enjoyment regarding AR-based experiential learning was, in descending order, "High (average: 4.22)", "Moderate (average: 4.18)", and "Low (average: 4.00)."

Regarding prior experience of environmental education on fine dust, "Relatively enjoyable" (46.5\%) was the response with the highest percentage for students with past educational engagement, and the same response (43.4\%) was also ranked as first for students without such experience. The degree of enjoyment derived from AR-based experiential learning was higher for students with prior educational experience (average: 4.28) than for those without it (average: 4.05). The difference in the degree 
of enjoyment based on such past educational engagement in fine dust had meaningful significance $(t=2.036, p<0.05)$. In other words, students who had previously received environmental education on fine dust enjoyed the AR-based experiential learning more than those without such experience.

As for prior experience using AR for the purpose of education, the response with the highest percentage was that the students enjoyed the program, regardless of previous use of the technology ("With" 84.0\%, "Without" 77.2\%). The degree of enjoyment derived from AR-based experiential learning was higher for "With" experience (average: 4.26) than for "Without" experience (average: 4.14).

On the question about the usefulness of the AR-based experiential learning in fine dust environmental education, "Relatively useful" $(41.8 \%)$ had the highest percentage of responses, followed by "Very useful" (39.0\%) (Table 14). These results demonstrated that the AR-based experiential learning was beneficial.

Table 14. Usefulness of environmental education using AR.

\begin{tabular}{|c|c|c|c|c|c|c|c|c|c|}
\hline \multirow{2}{*}{$\begin{array}{l}\text { Type } \\
\text { Total }\end{array}$} & & \multirow{2}{*}{$\begin{array}{c}\text { Sample } \\
182\end{array}$} & \multirow{2}{*}{$\begin{array}{c}\begin{array}{c}3 \\
(\%)\end{array} \\
18.1\end{array}$} & \multirow{2}{*}{$\begin{array}{c}\begin{array}{c}4 \\
(\%)\end{array} \\
41.8\end{array}$} & \multirow{2}{*}{$\begin{array}{c}\mathbf{5} \\
(\%)\end{array}$} & \multirow{2}{*}{$\begin{array}{c}\text { N/A } \\
1.1\end{array}$} & \multicolumn{2}{|c|}{$\begin{array}{l}\text { Mean (Std.) } \\
\text { (Point) }\end{array}$} & \multirow[t]{2}{*}{$F / t$} \\
\hline & & & & & & & 4.21 & $(0.73)$ & \\
\hline \multirow{3}{*}{$\begin{array}{l}\text { Degree of Interest } \\
\text { in Fine Dust }\end{array}$} & High & 93 & 14.0 & 45.2 & 38.7 & 2.2 & 4.25 & $(0.69)$ & \multirow{3}{*}{$\begin{array}{l}F=0.789 \\
p=0.456\end{array}$} \\
\hline & Moderate & 65 & 20.0 & 38.5 & 41.5 & 0.0 & 4.22 & $(0.76)$ & \\
\hline & Low & 24 & 29.2 & 37.5 & 33.3 & 0.0 & 4.04 & $(0.81)$ & \\
\hline \multirow{2}{*}{$\begin{array}{l}\text { Learning } \\
\text { Experience }\end{array}$} & Yes & 99 & 13.1 & 46.5 & 39.4 & 1.0 & 4.27 & $(0.68)$ & \multirow{2}{*}{$\begin{array}{l}t=1.086 \\
p=0.279\end{array}$} \\
\hline & No & 83 & 24.1 & 36.1 & 38.6 & 1.2 & 4.15 & $(0.79)$ & \\
\hline \multirow{2}{*}{$\begin{array}{l}\text { AR Utilization } \\
\text { Experience }\end{array}$} & Yes & 50 & 14.0 & 44.0 & 38.0 & 4.0 & 4.25 & $(0.70)$ & \multirow{2}{*}{$\begin{array}{l}t=0.429 \\
p=0.669\end{array}$} \\
\hline & No & 132 & 19.7 & 40.9 & 39.4 & 0.0 & 4.20 & $(0.75)$ & \\
\hline
\end{tabular}

Unit: Number of persons, \%, Point. (1) Education experience was based on the entire experience of fine dust environment education in elementary, middle, and high schools. (2) AR utilization experience means experience using AR for educational purposes prior to practical fine dust environment classes.

In relation to the degree of interest in fine dust, "Relatively useful (45.2\%)" and "Very useful $(38.7 \%)^{\prime \prime}$ were the top two responses for students with a high degree of interest, whereas for students with a moderate degree of interest, "Very useful (41.5\%)" was higher than "Relatively useful (38.5\%)." As for the students with a low degree of interest, the order of the responses was "Relatively useful $(37.5 \%)$ " and "Very useful (33.3\%)." The degree of perceived usefulness of the AR-based experiential learning was highest for the students with a high degree of interest (average: 4.25), followed by students with a moderate degree of interest (average: 4.22), and those with a low degree of interest (average: 4.04).

With regard to prior experience in environmental education on fine dust, the majority of students with such experience chose "Relatively useful $(46.5 \%)$ ", while those without such experience mostly responded that the education was "Very useful (38.6\%)". The degree of perceived usefulness of the AR-based experiential learning was higher for those with past engagement in fine dust education ("With" average: 4.27) than for those without such experience ("Without" average: 4.15).

As for the prior use of AR for educational purposes, "Relatively useful" was the response with the highest percentage, regardless of previous experience with AR technology ("With" 44.0\%, "Without" $40.9 \%$ ). The degree of perceived usefulness of the AR-based experiential learning was, on average, 4.25 for students with experience in the use of AR in education and 4.20 for those without such experience.

In observing the degree of active participation by students in the AR-based experiential learning, responses with high percentages were, in descending order, "Relatively active (40.7\%)," "Very active $(35.2 \%), "$ and "Moderate (20.9\%)" (Table 15). 
Table 15. The degree of active participation in AR-based environmental education.

\begin{tabular}{|c|c|c|c|c|c|c|c|c|c|c|c|}
\hline Type & & Sample & 1 & 2 & 3 & 4 & 5 & N/A & \multicolumn{2}{|c|}{ Mean (Std.) } & $F / t$ \\
\hline Total & & 182 & 0.5 & 1.6 & 20.9 & 40.7 & 35.2 & 1.1 & 4.09 & $(0.82)$ & \\
\hline \multirow{3}{*}{$\begin{array}{l}\text { Degree of Interest } \\
\text { in Fine Dust }\end{array}$} & High & 93 & 1.1 & 3.2 & 18.3 & 43.0 & 32.3 & 2.2 & 4.04 & $(0.87)$ & \multirow{3}{*}{$\begin{array}{l}F=0.861 \\
p=0.424\end{array}$} \\
\hline & Moderate & 65 & 0.0 & 0.0 & 21.5 & 36.9 & 41.5 & 0.0 & 4.20 & $(0.77)$ & \\
\hline & Low & 24 & 0.0 & 0.0 & 29.2 & 41.7 & 29.2 & 0.0 & 4.00 & $(0.78)$ & \\
\hline \multirow{2}{*}{$\begin{array}{l}\text { Learning } \\
\text { Experience }\end{array}$} & Yes & 99 & 0.0 & 0.0 & 17.2 & 46.5 & 35.4 & 1.0 & 4.18 & $(0.71)$ & \multirow{2}{*}{$\begin{array}{l}t=1.596 \\
p=0.112\end{array}$} \\
\hline & No & 83 & 1.2 & 3.6 & 25.3 & 33.7 & 34.9 & 1.2 & 3.99 & $(0.94)$ & \\
\hline \multirow{2}{*}{$\begin{array}{l}\text { AR Utilization } \\
\text { Experience }\end{array}$} & Yes & 50 & 0.0 & 2.0 & 14.0 & 48.0 & 32.0 & 4.0 & 4.15 & $(0.74)$ & \multirow{2}{*}{$\begin{array}{l}t=0.504 \\
p=0.615\end{array}$} \\
\hline & No & 132 & 0.8 & 1.5 & 23.5 & 37.9 & 36.4 & 0.0 & 4.08 & $(0.85)$ & \\
\hline
\end{tabular}

Unit: Number of persons, \%, Point. (1) Education experience was based on the entire experience of fine dust environment education in elementary, middle, and high schools. (2) AR utilization experience means experience using AR for educational purposes prior to the practical fine dust environment classes.

In relation to the degree of interest in fine dust, "Relatively active" had the highest percentages regarding the degree of active participation by students with high and low degrees of interest ("High" $43.0 \%$, "Low" 41.7\%). As for students with a moderate degree of interest, "Very active (41.5\%)" was the response with the highest percentage. The degree of active participation in the AR-based experiential learning was the highest for students with a high degree of interest in fine dust (average: 4.04), followed by those with a moderate degree of interest (average: 4.20) and a low degree of interest (average: 4.00).

With regard to prior experience in environmental education on fine dust, "Relatively active (46.5\%)" was the response with the highest percentage for students with such experience, whereas "Very active $(34.9 \%)$ " was the top choice for those without such experience. The degree of active participation in the AR-based experiential learning on fine dust environmental education was higher for students with prior experience (average: 4.18) than for students without it (average: 3.99).

As for the prior use of AR for educational purposes, "Relatively active" was the response with the highest percentage, regardless of past experience with AR technology ("With" 48.0\%, "Without" 37.9\%). The degree of active participation in the AR-based experiential learning was, on average, 4.15 for students with experience and 4.08 for those without such experience.

Regarding the question of whether the AR-based class helped the students to better understand the study materials compared to regular classes, "Relatively helpful (41.2\%)" and "Very helpful (41.2\%)" were the two responses with the highest percentages (Table 16). Such a result indicates that the utilization of AR in education may help enable a better understanding of study materials through the use of visual effects to arouse students' interest and induce active participation.

Table 16. The degree of helpfulness of AR/VR-based education in understanding the study materials.

\begin{tabular}{|c|c|c|c|c|c|c|c|c|c|c|}
\hline \multirow{2}{*}{\multicolumn{2}{|c|}{$\begin{array}{l}\text { Type } \\
\text { Total }\end{array}$}} & \multirow{2}{*}{$\begin{array}{l}\text { Sample } \\
182\end{array}$} & \multirow{2}{*}{$\begin{array}{c}2 \\
2.7\end{array}$} & \multirow{2}{*}{$\frac{3}{13.7}$} & \multirow{2}{*}{$\begin{array}{c}4 \\
41.2\end{array}$} & \multirow{2}{*}{$\begin{array}{c}5 \\
41.2\end{array}$} & \multirow{2}{*}{$\frac{\text { N/A }}{1.1}$} & \multicolumn{2}{|c|}{ Mean(Std.) } & \multirow[t]{2}{*}{$F / t$} \\
\hline & & & & & & & & 4.22 & $(0.79)$ & \\
\hline \multirow{3}{*}{$\begin{array}{c}\text { Degree } \\
\text { of Interest } \\
\text { in Fine Dust }\end{array}$} & High & 93 & 2.2 & 11.8 & 39.8 & 44.1 & 2.2 & 4.29 & $(0.76)$ & \multirow{3}{*}{$\begin{array}{l}F=1.256 \\
p=0.287\end{array}$} \\
\hline & Moderate & 65 & 1.5 & 13.8 & 46.2 & 38.5 & 0.0 & 4.22 & $(0.74)$ & \\
\hline & Low & 24 & 8.3 & 20.8 & 33.3 & 37.5 & 0.0 & 4.00 & $(0.98)$ & \\
\hline \multirow{2}{*}{$\begin{array}{l}\text { Learning } \\
\text { Experience }\end{array}$} & Yes & 99 & 2.0 & 10.1 & 46.5 & 40.4 & 1.0 & 4.27 & $(0.73)$ & \multirow{2}{*}{$\begin{aligned} t & =0.801 \\
p & =0.424\end{aligned}$} \\
\hline & No & 83 & 3.6 & 18.1 & 34.9 & 42.2 & 1.2 & 4.17 & $(0.86)$ & \\
\hline \multirow{2}{*}{$\begin{array}{l}\text { AR Utilization } \\
\text { Experience }\end{array}$} & Yes & 50 & 2.0 & 6.0 & 50.0 & 38.0 & 4.0 & 4.29 & $(0.68)$ & \multirow{2}{*}{$\begin{array}{l}t=0.712 \\
p=0.477\end{array}$} \\
\hline & No & 132 & 3.0 & 16.7 & 37.9 & 42.4 & 0.0 & 4.20 & $(0.82)$ & \\
\hline
\end{tabular}

Unit: Number of person, \%, Point. (1) Education experience was based on the entire experience of fine dust environment education in elementary, middle and high schools. (2) AR utilization experience means experience using AR for educational purposes prior to the practical fine dust environment classes. 
In relation to the degree of interest in fine dust, "Very helpful" was the response with the highest percentage for students with both high and low degrees of interest ("High" 44.1\%, "Low" 37.5\%). The degree of helpfulness of AR-based education in understanding the study materials was, on average, 4.29 for students with a high degree of interest in fine dust, 4.22 for those with a moderate degree of interest, and 4.00 for those with a low degree of interest.

With regard to prior experience in environmental education on fine dust, "Relatively helpful $(46.5 \%)$ " was the response with the highest percentage for students with such educational experience, whereas "Very helpful (42.2\%)" was the most chosen answer for those without such experience. The degree of helpfulness of AR-based education on understanding the study materials was, on average, 4.27 for students with prior experience in environmental education on fine dust and 4.17 for those without such experience.

As for the prior use of AR technology for educational purposes, "Relatively helpful (50.0\%)" was the response with the highest percentage for students with prior experience using AR, whereas "Very helpful $(42.4 \%)^{\prime \prime}$ was the highest for students without prior experience with such technology. The degree of helpfulness of AR-based education on understanding the study materials was, on average, 4.29 for students with experience with AR technology and 4.20 for those without previous usage.

\section{Discussion}

\subsection{The Effect of AR Utilization}

Researchers have been developing curricula using various methods and studying their outcomes to achieve more productive pedagogical approaches. As problems arose in teaching with the use of text, a study that emphasized the importance of learning based on experience was proposed by [27], who highlighted that effective learning comes from direct experience. It has been argued that the value of experience is based on the situation, and that genuine learning is achievable through actual participation [28]. In modern times, participatory learning based upon various experiences, such as practical training, field trips, and problem-solving studies, has been developed for experimental and experiential education [29].

However, such hands-on learning is often impossible in limited spaces such as in schools, and outdoor activities are only possible within the boundaries of certain conditions. For example, an explanation of natural phenomena, education about anatomy, or experiential learning, such as studies of nature or observation of ecology, has limitations in terms of the difficulty of experience in the classroom. Fine dust is invisible to the eye, and the principles of its impacts on the human body cannot be concretized through experiments. Therefore, it is impossible to acquire experiential knowledge either indoors or outdoors, which is a significant problem in fine dust education, as students are directly affected by exposure to fine dust.

However, AR technology has made a breakthrough in this regard. The principles and harmfulness of fine dust can be visualized and expressed to students. Fine dust related information can be provided through activities that enable the students to obtain information by performing various activities using mobile devices.

Overall, AR in fine dust education has given rise to more remarkable results than initially expected. The reason AR has such a positive effect on learning is believed to be due to its capacity to stimulate various human cognitive abilities.

Another reason is that $\mathrm{AR}$ allows for easier explanations of direct observation and dangerous phenomena, and it can embody abstract concepts [30,31]. This function can enhance students' understanding and arouse their interest and motivation [32]. In particular, AR is known to help engrave information into the minds of users by deploying visual and spatial awareness capabilities. In the research by [14], AR was used to help explain the anatomy of three-dimensional human bodies. It was demonstrated that three-dimensional visualization technology, a form of computer-based 
education, was effective in anatomy education [33]. In particular, virtual objects used in classes on anatomy were shown to have positive educational effects [34,35].

\subsection{Awareness of and Attitudes towards Fine Dust among Students before the Application of AR}

As with the results of this study, high school students' perception and attitudes in responding to fine dust show that despite high levels of awareness, their attitudes are not as active. Such results can be found in previous studies on fine dust awareness.

In a study of university students, the level of awareness on fine dust was 3.59 out of 5.0. A level of attitude of 3.18 indicated a clear difference between perception and attitude [36]. The students did not have accurate knowledge of the definition of fine dust, and attitudes reflecting practical aspects were not affected by perception [37].

In a more recent survey [1], 92.3\% of respondents acknowledged that the concentration of fine dust had increased significantly $(92.3 \%)$ compared to 10 years ago, and that the damage was severe (94.7\%) compared to that in developed countries. Additionally, $60 \%$ to $70 \%$ of respondents also showed anxiety, displeasure, and discomfort. However, only $54.8 \%$ of respondents used forewarning systems to consider wearing masks outdoors, which is a relatively low figure.

Such a result indicates that knowledge does not correlate with actual practice [38], and that the transmission of information alone does not to help determine risk and change behavior [39]. It has been shown that this phenomenon is due to the determination of risk by the subjective judgment of the individual, rather than by scientifically proven relative risk or statistical estimates based on, for example, numbers of fatalities [40]. It has been noted that such inconsistencies in perception and practice are the result of miscommunication [41].

This matter can therefore be attributed to problems in information delivery or education and learning, which should encourage the development of correct subjective judgments through proper communication. Therefore, the general public should be able to draw a sketch of the concept of fine dust based on the key messages needed for risk assessment, and further link the information provided in fragments to such a foundation in order to understand the phenomenon [42,43]. To overcome these shortcomings, it is necessary to develop educational methods that fit the characteristics of the target audience [44].

\subsection{Benefits of AR-Based Education}

In light of the results of this study, it has been confirmed that AR technology can serve as a tool to reconcile inconsistencies in perception and practice. According to the survey results on satisfaction, the existing methods of education were uninteresting to students and did not effectively stimulate their motivation to learn. As a result, students did not have high expectations or interest in learning about fine dust. However, the use of AR reduced the percentage of responses indicating a moderate degree of interest and enjoyment from $52.5 \%$ to $19.8 \%$, and increased the percentage of responses "satisfied" and "very satisfied" from $26.0 \%$ and $4.0 \%$ to $39.6 \%$ and $39.6 \%$, respectively. Overall, the degree of satisfaction was enhanced from $30.7 \%$ to $79.2 \%$, demonstrating the potential of AR-based education. In addition, nearly $80 \%$ of students perceived the AR-based education on fine dust as useful, confirming that the utilization of AR technology had a positive effect.

Additionally, students' educational experience in learning about the environment and fine dust can change their perception of the environment and become a driving force that could further strengthen personal hygiene management. This finding confirms the sustainable aspect of such education, with its impact on the environment and personal hygiene. Thanks to an effective pedagogical approach, these changes to personal hygiene management may help students build a stronger foundation to grow into adults who are able to achieve a sustainable environment and society by making efforts to protect the environment and reduce fine dust. 


\subsection{Students' Attitudes toward the Use of AR}

After receiving the AR-based education on fine dust, more than $75 \%$ of students actively participated in learning. Additionally, judging from the positive results shown in terms of students' attitudes toward fine dust, regardless of their interest or educational experience, it can be hypothesized that AR technology in education has the potential to cause changes in students' attitudes by motivating them to learn and actively engage in their education.

In other words, AR technology effected changes in attitude by prompting students to actively show a greater degree of interest. In fact, it has been argued that AR could strengthen students' motivation to learn, which is in line with the our finding that students show positive attitudes toward AR-based learning [45]. The study by [46] also demonstrated that the application of AR to science education resulted in enhanced academic performance and improved attitudes among middle school students.

However, the usability of AR is dependent upon the motivation to learn. As mentioned by [47], students facing educational difficulties had a negative attitude toward such learning. The use of AR can have a synergistic effect only when it is easy to manipulate and can increase the degree of students' enjoyment and interest.

Regarding the usability of AR and the enjoyment and interest in AR activities that follow, it has been argued that AR activities give pleasure to and prompt enthusiasm in students. Students also did not show any signs of concern when using the technology [46]. The AR systems were easy to use and found to be useful for students studying anatomy [48]; furthermore, academic groups using AR achieved higher test scores than those that did not $[49,50]$. Groups that received education in which AR was applied also had a higher level of understanding of three-dimensional figures [51]. In other words, AR can be seen as a highly effective medium in terms of its usability and effectiveness compared to traditional learning methods.

\subsection{Students' Understanding and Motivation regarding Fine Dust}

It has been proven through this research that Augmented Reality (AR), which allows for experience through virtual spaces with the adoption of technical elements, can be an alternative method in cases where hands-on practice is not possible. Notably, $82.4 \%$ of students responded that AR technology had helped them enhance their understanding of fine dust.

In the study by [13], applying AR in scientific education enhanced students' understanding of geography and also their levels of achievement [52]. By visualizing invisible phenomena such as magnetic fields, AR technology helps students understand the subject in detail [53] and improves motivation for students to learn [54].

\subsection{Effect of AR-Based Fine Dust Education}

The fact that AR-based education was effective regardless of prior experience in fine dust education is enough to recognize the effect of adopting a new method of education using AR. In consideration of the recent educational trend emphasizing experiential learning, AR, as demonstrated in this study, provides a semirealistic experience, and its effect is thus more substantial than that of two-dimensional or audiovisual learning materials which are traditionally used in classes. Concepts that are difficult to visualize in the real world, such as issues associated with fine dust, cannot be adequately represented in classrooms. However, AR has a significant effect on the teaching of abstract concepts or phenomena. It can show specific symptoms upon exposure to fine dust by visualizing the harmfulness of fine dust on the human body, the progress of its impact, and the possible diseases it may cause in each part of the body. It has also been mentioned that AR concretizes and visualizes abstract concepts to enhance students' understanding and enable observation of phenomena which are not subject to experience in real life [55]. Therefore, the application of AR in this study positively impacted the students in general, as it raised awareness of fine dust and effected the changes in the degree of implementation of fine dust-related activities. 


\subsection{Issues and Limitations}

The survey in this study was conducted on only a limited number of students in the first year of high school. This experiment is thus be limited to explaining this particular case only. Overall, the study result is not applicable to other students and the public. In order to make broader observations, it would be necessary to incorporate a wider range of targets and perform additional experiments.

\section{Conclusions}

This study observed changes in the awareness and attitudes of first-year high school students with regard to fine dust. It investigated whether AR-based education had the potential to change students' awareness of and attitudes to this matter.

About half (51.1\%) of the target students had an interest in fine dust issues; $94.0 \%$ of students responded that the recent problem of fine dust in Korea was severe, and students with a high degree of interest in fine dust tended to perceive the issue as being even more severe ("High" average: 4.68; "Moderate" average: 4.25; "Low" average: 3.96). On the perceived severity of the fine dust problem in schools, $47.8 \%$ viewed it as moderate, whereas $44.0 \%$ perceived it as being severe. As for the problem of fine dust in schools, there was a tendency for students who had a high degree of interest to view the issue as severe ("High" average: 3.68; "Moderate" average: 3.33; "Low" average: 3.08).

With regard to the degree of implementation of activities related to fine dust in daily life, students had a moderate degree of implementation (average: 3.35), and students with a high degree of interest in fine dust had a greater tendency to implement such activities ("High" average: 3.63; "Moderate" average: 3.14; "Low" average: 2.83). Such a result indicated that for students to protect themselves from problems associated with fine dust, it is necessary to make sure that they are exposed to an environment in which they can first gain interest in fine dust-related issues.

Only about half of the students had prior educational experience with fine dust, i.e., $54.4 \%$ percentage. Since 2015 , schools have been obliged to designate a person in charge of fine dust-related matters to create a safer school environment and strengthen relevant education. Still, only half of the students indicated that they had received such education. This indicates a lack of education provided regularly in schools or the provision of education at a level that students cannot clearly acknowledge.

It was found that for students with educational experience with fine dust, most of the relevant programs were conducted in the form of lectures or videos $(80.2 \%)$ taught by guest instructors $(80.2 \%)$ in schools $(88.1 \%)$. The level of satisfaction among students with such education was moderate (average: 3.23), and the majority of the respondents viewed the contents as uninteresting, as the classes were "focused on theoretical background (80.0\%)." As for the teaching methods, 45.1\% indicated satisfaction with "AR experiential learning with a focus on education" and $26.4 \%$ with "education using audiovisual materials such as video clips." This outcome demonstrates that students favor learning in the form of new technology as opposed to traditional lectures.

There was an increase in the degree of implementation of fine dust-related activities in daily life after receiving the AR-based experiential learning on fine dust environmental education compared to before the education (Pretest average: 3.35; Posttest average: 4.23). The increase rate was higher for the groups with low interest in fine dust $(\Delta 1.39)$ and without prior experience in fine dust education $(\Delta 0.99)$. There were improvements in all 12 survey items that were used to assess the degree of implementation of fine dust-related activities in daily life after the students received the AR-based education. Notably, there were significant improvements for the following survey items: "I try to reduce the amount of fine dust when I change into or out of my gym clothes or during physical education classes $(\Delta 1.42),{ }^{\prime \prime}$ "I adjust the commuting time to and from school and check whether the school is closed $(\Delta 1.33), "$ and "I prepare personal hygiene products such as yellow dust masks, handkerchiefs, and tissues $(\Delta 1.20) . "$ Considering that the objective of fine dust environmental education is not understanding a theory but, rather, maintaining individual health through practices in real life, the use of AR in experiential learning as applied in this study was shown to have a certain positive effect. 
With regard to the educational effect of using AR based on the degree of interest, the result was valid for all students in this study; a particularly notable finding was that the AR-based education was more effective for students with a moderate or low degree of interest in fine dust. Such a result suggests that AR-based education has the potential to bring about substantial benefits in achieving educational objectives by encouraging students to actively engage in learning, even for those with less interest in the subject. As for the effect of education based on prior educational experience, it was confirmed in this research that AR-based education enabled students without background knowledge of fine dust to easily approach the concept, and induced changes in their attitudes. Additionally, the effect of AR technology in education on fine dust was found to contribute to environmental sustainability by reinforcing students' attitudes and behavior in a positive way, i.e., by inducing changes in their lifestyle to protect themselves and the environment.

Author Contributions: Conceptualization, K.J.B. and J.R.H.; methodology, J.R.H., I.-J.P. and K.J.B.; software, J.R.H.; validation, K.J.B. and I.-J.P.; formal analysis, J.R.H.; investigation, K.J.B., I.-J.P.; resources, K.J.B., Y.S. and H.J.C.; data curation, J.R.H. and H.J.C.; writing - original draft preparation, K.J.B.; writing-review and editing, K.J.B. and J.R.H.; visualization, K.J.B. and J.R.H.; supervision, K.J.B. and I.-J.P.; project administration, J.R.H.; funding acquisition, J.R.H. and K.J.B. All authors have read and agreed to the published version of the manuscript.

Funding: This research is supported by Korea Ministry of Environment (MOE) as “Environment Technology Development Project." [Grant number: 2019000160006].

Conflicts of Interest: The authors declare no conflict of interest.

\section{References}

1. Shin, D.W.; Joo, H.S.; Lee, G.E. Fine Dust Public Awareness Survey; Korea Environment Institute Sejong: Sejong, Korea, 2019.

2. Dede, C. Immersive interfaces for engagement and learning. Science 2009, 323, 66-69. [CrossRef]

3. Arvanitis, T.N.; Petrou, A.; Knight, J.F.; Savas, S.; Sotiriou, S.; Gargalakos, M.; Gialouri, E. Human factors and qualitative pedagogical evaluation of a mobile augmented reality system for science education used by learners with physical disabilities. Pers. Ubiquitous Comput. 2009, 13, 243-250. [CrossRef]

4. Dunleavy, M.; Dede, C.; Mitchell, R. Affordances and limitations of immersive participatory augmented reality simulations for teaching and learning. J. Sci. Educ. Technol. 2009, 18, 7-22. [CrossRef]

5. Squire, K.D.; Jan, M. Mad City Mystery: Developing scientific argumentation skills with a place-based augmented reality game on handheld computers. J. Sci. Educ. Technol. 2007, 16, 5-29. [CrossRef]

6. Alahmari, M.; Issa, T.; Issa, T.; Nau, S.Z. Faculty awareness of the economic and environmental benefits of augmented reality for sustainability in Saudi Arabian universities. J. Clean. Prod. 2019, 226, 259-269. [CrossRef]

7. Cai, S.; Wang, X.; Chiang, F.-K. A case study of Augmented Reality simulation system application in a chemistry course. Comput. Hum. Behav. 2014, 37, 31-40. [CrossRef]

8. Klopfer, E.; Sheldon, J. Augmenting your own reality: Student authoring of science-based augmented reality games. New Dir. Youth Dev. 2010, 2010, 85-94. [CrossRef] [PubMed]

9. Liu, W.; Cheok, A.D.; Mei-Ling, C.L.; Theng, Y.-L. Mixed Reality Classroom: Learning from Entertainment; Association for Computing Machinery: Perth, Australia, 2007; pp. 65-72.

10. Kerawalla, L.; Luckin, R.; Seljeflot, S.; Woolard, A. "Making it real”: Exploring the potential of augmented reality for teaching primary school science. Virtual Real. 2006, 10, 163-174. [CrossRef]

11. Wu, H.-K.; Lee, S.W.-Y.; Chang, H.-Y.; Liang, J.-C. Current status, opportunities and challenges of augmented reality in education. Comput. Educ. 2013, 62, 41-49. [CrossRef]

12. Chytas, D.; Johnson, E.O.; Piagkou, M.; Mazarakis, A.; Babis, G.C.; Chronopoulos, E.; Nikolaou, V.S.; Lazaridis, N.; Natsis, K. The role of augmented reality in Anatomical education: An overview. Ann. Anat. -Anat. Anz. 2020, 229, 151463. [CrossRef]

13. Shelton, B.E.; Hedley, N.R. Using augmented reality for teaching earth-sun relationships to undergraduate geography students. In Proceedings of the First IEEE International Workshop Agumented Reality Toolkit, Darmstadt, Germany, 29 September 2002; p. 8.

14. Ma, M.; Fallavollita, P.; Seelbach, I.; Von Der Heide, A.M.; Euler, E.; Waschke, J.; Navab, N. Personalized augmented reality for anatomy education. Clin. Anat. 2016, 29, 446-453. [CrossRef] [PubMed] 
15. Kamphuis, C.; Barsom, E.; Schijven, M.; Christoph, N. Augmented reality in medical education? Perspect. Med. Educ. 2014, 3, 300-311. [CrossRef] [PubMed]

16. Yammine, K.; Violato, C. A meta-analysis of the educational effectiveness of three-dimensional visualization technologies in teaching anatomy. Anat. Sci. Educ. 2015, 8, 525-538. [CrossRef] [PubMed]

17. Brenton, H.; Hernandez, J.; Bello, F.; Strutton, P.; Purkayastha, S.; Firth, T.; Darzi, A. Using multimedia and Web3D to enhance anatomy teaching. Comput. Educ. 2007, 49, 32-53. [CrossRef]

18. Garg, A.; Norman, G.R.; Spero, L.; Maheshwari, P. Do virtual computer models hinder anatomy learning? Acad. Med. 1999, 74, S87-S89. [CrossRef] [PubMed]

19. Garg, A.X.; Norman, G.; Sperotable, L. How medical students learn spatial anatomy. Lancet 2001, 357, 363-364. [CrossRef]

20. Garg, A.X.; Norman, G.R.; Eva, K.W.; Spero, L.; Sharan, S. Is there any real virtue of virtual reality?: The minor role of multiple orientations in learning anatomy from computers. Acad. Med. 2002, 77, S97-S99. [CrossRef]

21. Son, Y.-A.; Park, J.-E.; Min, B.-M.; Choi, D.-H. Analyzing the Status of Environment-related Teaching in Elementary and Secondary Schools. Korean J. Environ. Educ. 2007, 20, 45-62.

22. An, S.H.; Kim, H.S.; Hwang, J.S.; Ju, G.H.; Seo, J.H.; An, S.H.; Lee, S.H.; Lee, J.T. A study on Analysis of Actual Use of Digital Textbooks and Future Plans. In KR 2020-2; Korea Education and Research Information Service: Daegu, Korea, 2020.

23. Markowitz, D.M.; Laha, R.; Perone, B.P.; Pea, R.D.; Bailenson, J.N. Immersive virtual reality field trips facilitate learning about climate change. Front. Psychol. 2018, 9, 2364. [CrossRef]

24. Kamarainen, A.M.; Metcalf, S.; Grotzer, T.; Browne, A.; Mazzuca, D.; Tutwiler, M.S.; Dede, C. EcoMOBILE: Integrating augmented reality and probeware with environmental education field trips. Comput. Educ. 2013, 68, 545-556. [CrossRef]

25. Akçayır, M.; Akçayır, G. Advantages and challenges associated with augmented reality for education: A systematic review of the literature. Educ. Res. Rev. 2017, 20, 1-11. [CrossRef]

26. Nincarean, D.; Alia, M.B.; Halim, N.D.A.; Rahman, M.H.A. Mobile Augmented Reality: The potential for education. Procedia-Soc. Behav. Sci. 2013, 103, 657-664. [CrossRef]

27. Dewey, D.P. A comparison of reading development by learners of Japanese in intensive domestic immersion and study abroad contexts. Stud. Second Lang. Acquis. 2004, 26, 303-327.

28. Lave, J.; Wenger, E. Situated Learning Legitimate Peripheral Participation; Cambridge University Press: Cambridge, UK, 1991.

29. Kwon, C. Verification of the possibility and effectiveness of experiential learning using HMD-based immersive VR technologies. Virtual Real. 2019, 23, 101-118. [CrossRef]

30. Somyurek, S. Attracting Z generation's attention in learning process: Augmented reality. Educ. Technol. Theory Implement. 2014, 4, 63-80.

31. Walczak, K.; Wojciechowski, R.; Cellary, W. Dynamic interactive VR network services for education. In Proceedings of the ACM symposium on Virtual reality software and technology, Limassol, Cyprus, 1-3 November 2006; pp. 277-286.

32. Chen, C.-M.; Tsai, Y.-N. Interactive augmented reality system for enhancing library instruction in elementary schools. Comput. Educ. 2012, 59, 638-652. [CrossRef]

33. Hackett, M.; Proctor, M. Three-dimensional display technologies for anatomical education: A literature Review. J. Sci. Educ. Technol. 2016, 25, 641-654. [CrossRef]

34. Falah, J.; Charissis, V.; Khan, S.; Chan, W.; Alfalah, S.F.; Harrison, D.K. Development and evaluation of virtual reality medical training system for anatomy education. J. Sci. Math.Technol. 2015, 591, 369-383.

35. Said, C.S.; Shamsudin, K.; Mailok, R.; Johan, R.; Hanaif, H.F. The development and evaluation of a 3D visualization tool in anatomy education. J. Sci. Math. Technol. 2015, 2, 48-56.

36. Choi, S.-H. A study on the factors affecting fine dust cognition, knowledge, and attitude among college students. J. Korea Contents Assoc. 2018, 18, 281-290.

37. Park, E.; Oh, H.-J.; Kim, S.-H.; Min, A. The relationships between particulate matter risk perception, knowledge, and health promoting behaviors among college students. J. Korean Biol. Nurs. Sci. 2018, 20, 20-29. [CrossRef]

38. Hall, E.; Chai, W.; Koszewski, W.; Albrecht, J. Development and validation of a social cognitive theory-based survey for elementary nutrition education program. Int. J. Behav. Nutr. Phys. Act. 2015, 12, 47. [CrossRef] [PubMed] 
39. Morgan, M.G.; Fischhoff, B.; Bostrom, A.; Atman, C.J. Risk Communication: A Mental Models Approach; Cambridge University Press: Cambridge, UK, 2002; pp. 1-350.

40. Paul, S. The perception of risk. In Risk, Society, and Policy Series; Earthscan Publications: Washington, DC, USA, 2016; pp. 179-182.

41. Kim, Y.; Lee, H.; Lee, H.; Jang, Y. A study on differences between experts and lay people about risk perceptions toward particular matter: A focus on the utilization of mental models. Commun. Theor. 2016, 12, 53-117.

42. Damman, O.C.; Timmermans, D.R. Educating health consumers about cardio-metabolic health risk: What can we learn from lay mental models of risk? Patient Educ. Couns. 2012, 89, 300-308. [CrossRef]

43. Hibbard, J.H.; Greene, J.; Daniel, D. What is quality anyway? Performance reports that clearly communicate to consumers the meaning of quality of care. Med. Care Res. Rev. 2010, 67, 275-293. [CrossRef] [PubMed]

44. Lee, H.; Cha, S.-A.; Kwon, H.-N. Study on the effect of augmented reality contents-based instruction for adult learners on academic achievement, interest and flow. J. Korea Contents Assoc. 2016, 16, 424-437. [CrossRef]

45. Borrero, A.M.; Márquez, J.A. A pilot study of the effectiveness of augmented reality to enhance the use of remote labs in electrical engineering education. J. Sci. Educ. Technol. 2012, 21, 540-557. [CrossRef]

46. Sahin, D.; Yilmaz, R.M. The effect of Augmented Reality Technology on middle school students' achievements and attitudes towards science education. Comput. Educ. 2020, 144, 103710. [CrossRef]

47. Gundogdu, T. The Analysis of the Relationship between 8th Grade Students' Success and Conceptual Understanding of Astronomy and Their Attitudes towards Science Courses; Marmara University Institute of Educational Sciences: Istanbul, Turkey, 2014.

48. Thomas, R.G.; William John, N.; Delieu, J.M. Augmented reality for anatomical education. J. Vis. Commun. Med. 2010, 33, 6-15. [CrossRef]

49. Ferrer-Torregrosa, J.; Torralba, J.; Jimenez, M.; García, S.; Barcia, J. ARBOOK: Development and assessment of a tool based on augmented reality for anatomy. J. Sci. Educ. Technol. 2015, 24, 119-124. [CrossRef]

50. Küçük, S.; Kapakin, S.; Göktaş, Y. Learning anatomy via mobile augmented reality: Effects on achievement and cognitive load. Anat. Sci. Educ. 2016, 9, 411-421. [PubMed]

51. Ferrer-Torregrosa, J.; Jiménez-Rodríguez, M.Á.; Torralba-Estelles, J.; Garzón-Farinós, F.; Pérez-Bermejo, M.; Fernández-Ehrling, N. Distance learning ects and flipped classroom in the anatomy learning: Comparative study of the use of augmented reality, video and notes. BMC Med. Educ. 2016, 16, 230.

52. Wang, C.-H.; Chi, P.-H. Applying augmented reality in teaching fundamental earth science in junior high schools. In Computer Applications for Database, Education, and Ubiquitous Computing; Kim, T.-H., Ma, J., Fang, W.-C., Zhang, Y., Cuzzocrea, A., Eds.; Springer: New York, NY, USA, 2012; Volume 352, pp. $23-30$.

53. Abdüsselam, M.S. Teachers' and students' views on using augmented reality environments in physics education: 11th grade magnetism topic example. Pegem Ĕ̆itim ve Öğretim Dergisi 2014, 4, 59-74.

54. Kugelmann, D.; Stratmann, L.; Nühlen, N.; Bork, F.; Hoffmann, S.; Samarbarksh, G.; Pferschy, A.; von der Heide, A.M.; Eimannsberger, A.; Fallavollita, P. An augmented reality magic mirror as additive teaching device for gross anatomy. Ann. Anat.-Anat. Anz. 2018, 215, 71-77.

55. Arici, F.; Yildirim, P.; Caliklar, S.; Yilmaz, R. Research Trends in Using Augmented Reality in Scientific Education: Content-Bibliometric Cartographic Analysis. Comput. Educ. 2019, 142, 103647.

Publisher's Note: MDPI stays neutral with regard to jurisdictional claims in published maps and institutional affiliations.

(C) 2020 by the authors. Licensee MDPI, Basel, Switzerland. This article is an open access article distributed under the terms and conditions of the Creative Commons Attribution (CC BY) license (http://creativecommons.org/licenses/by/4.0/). 